\title{
Islamic Theology with A Multicultural Perspective as the Basis for Religious Learning in Yogyakarta State Elementary Schools
}

\author{
Sangkot Sirait
}

\section{ABSTRACT}

This study aims to describe the multicultural Islamic religious learning found in several state schools in the special region of Yogyakarta. The problem in this study is how a Muslim teacher teaches Islam where students consist of various religions and traditions. The method used to obtain data in this study is interviews, document, and observation. In addition, it is also seen from the textbooks used by Islamic religious teachers in learning. From the results of this study, it can be obtained data that the learning of Islamic religious education in Yogyakarta public schools contains and has multicultural nuances. This can be seen from the aspects of learning methods in the classroom, teacher, and student relations, and how to organize classes. At the end of the article, there are also teaching materials that are conveyed in learning such as, Qur'an, the history of Islamic culture, Islamic law, and morals. Each of these subjects is taught with the faith of a Muslim but with a multicultural perspective.

Keywords: Curriculum, democratic, multicultural Islamic, humanist.
Published Online: October 30, 2021

ISSN: $2736-4534$

DOI: $10.24018 /$ ejedu.2021.2.5.170

\section{S. Sirait*}

Sunan Kalijaga State Islamic University Yogyakarta, Indonesia.

(e-mail: sangkot_sirait@yahoo.co.id)

*Corresponding Author

\section{INTRODUCTION}

This paper is part of a research result on the Islamic religious learning model in State Elementary Schools in Yogyakarta one of the special areas in Indonesia. This research is funded by the State Budget organized by the Institute for Research and Community Service, State Islamic University Sunan Kalijaga Yogyakarta, Indonesia. Yogyakarta is a student center city visited by almost all Indonesian citizens consisting of various ethnic groups who study here. Yogyakarta initially had one original culture, namely Javanese culture. However, because Yogyakarta is a city that is the main destination for both study and tourism, a lot of people who come from outside the area are interested and live here. Many parents are interested in living in Yogyakarta because of the easy access to quality education for their children. Now, Yogyakarta is like a mini-Indonesia, which has a very large variety of immigrant cultures. Of course, such conditions also affect basic educational institutions in presenting religious learning in schools. Students in elementary schools in Yogyakarta are students whose parents come from various regions in Indonesia. Yogyakarta as a city that has various languages, ethnicities, races, religions, and beliefs are required to create a situation of national unity and integrity, as the ideals of the nation are reflected in the motto Bhineka Tunggal Ika, it means unity in diversity. James J. Fox said in a research paper: A study of the full linguistic repertoire of the student population in Yogyakarta would, I am certain, provide a world-class example of this kind of multilingual multiculturalism [1].
Religious education as an institution that is mandated to maintain unity and unity should also depart from the awareness of differences and different backgrounds. Understanding learning in elementary schools using a multiculturalism approach will at least support the creation of a potential culture of mutual respect and protection, especially for young students. These assumptions are the basis for establishing the concept and implementation of Islamic religious education learning in elementary schools.

Education in the Special Region of Yogyakarta consists of formal and non-formal education. Its implementation always develops in accordance with the growth and problems that occur in the people of Yogyakarta, both those related to the elements of the teacher, methodology, material to the community environment. In the context of Yogyakarta, as an area that has heterogeneity or multiculturalism, religious education that takes place in state schools always adjusts to this, because the purpose of education in formal forums (schools) is nothing but to educate and develop various aspects, including preparing students to be able to respond to all differences and diversity in society. The role of the school becomes very important, namely as a responsible institution when the people of Yogyakarta still encounter many obstacles related to differences, especially four things, namely the ethnicity, religion, race, and differences between groups (SARA) background. Schools are required to create and invite the community to always be responsive and solve SARA problems from each of them. When viewed from the role of religious teachers in realizing successful learning in elementary schools, religious teachers have a very big 
responsibility. The role of religious teachers is so important to help students become individuals who understand differences. Social studies programs should help students to increase respect for other people's cultures rather than just glorifying their own [2].

In the Yogyakarta area, the concept of education with a multicultural perspective has been integrated with the learning system, and this starts when students study in elementary school. The basis for learning multiculturalism at the Yogyakarta State Elementary School is that differences are a very valuable natural trait and are appreciated as a positive thing. The education system and student assignments are not limited by differences, whether gender, age, ethnicity, language, religion, status, or opportunity. Religious education teachers have helped students to give and take advantage of this democratic system of society. Diversity has been used as a tool to develop the effectiveness of instructional strategies when students learn religion in the classroom.

However, the integration of multicultural education into the curriculum and religious learning for basic education students is not an easy task, because students who should need the theological doctrine of their own religion, are faced with a different situation, namely being invited to realize that 'beside' there are still different communities, both different in religion, belief, and culture. This is what makes this research interesting to do, namely how schools and their academic community understand multiculturalism and how it is implemented in Islamic religious learning in the classroom. How do state elementary schools in Yogyakarta create processes, paradigms, and orientations, especially in the subject of Islamic religious education.

\section{Multicultural EducAtion}

Multicultural education is an idea or concept, an educational reform movement, and a process. It incorporates that the idea that all students, regardless of gender and social class, should have equal opportunity to learn in school. A mayor goal of multicultural education is to improve academic achievement for all [3]. Sonia Nieto defined: "Multicultural education is a process of comprehensive school reform and basic education for all students. It challenges and rejects racism and other forms of discrimination in school and society and accepts and affirms the pluralism (ethnic, racial, linguistic, religious, economic, and gender, among others) that students, their communities, and teachers reflect. Multicultural education permeates the school curriculum and instructional strategies, as well as the interactions among teachers, students, and families, and the very way that school conceptualize the nature of teaching and learning. Because it uses critical pedagogy, as its underlying philosophy and focuses on knowledge, reflection promotes democratic principles of social justice [4].

Multicultural education is often misrepresented, that is, only as material related to cultural groups, not seen as a process. Because it is a process, according to Banks there are five dimensions of multicultural education that should be met when it is applied:

1. Content integration: Content integration refers to the use of examples and content from a variety of cultures and groups to illustrate key concepts. The content should be logically placed and not be artificial. Some subject areassocial sciences, language, humanities-can incorporate multicultural content easier than others.

2. Knowledge construction: This dimension identifies knowledge as constructed by human therefore implying a subjective bias rather than objective neutrality. Thus, teachers should help students understand that knowledge is a reflection of the implicit cultural assumptions, frame of references, perspectives and biases of the authors.

3. Prejudice reduction: The curriculum and instructional practice should help students develop positive attitudes toward different racial, ethnic, and cultural groups. Children come to school with negative misconceptions toward certain groups.

4. Equity pedagogy: An equity pedagogy exists when teachers modify their teaching in ways that will facilitate the academic achievement of all students, irrespective of group membership. Thus, teacher will employ a variety of teaching styles that are consistent with the wide range of learning styles within various cultural groups and will engage in cultural learning in order to make their instruction the most effective.

5. Empowering school culture. A culture within the school that promotes gender, racial, and social class equity. The school culture and organization must be examined by all members of the staff, and all must participate in restructuring [5]. Multicultural education has benefits for all aspects of the educational enterprise. Teacher benefits by the training they receive in multicultural education in enhanced teaching skills, and so the students benefit form multicultural education through increased access to knowledge and from expanded opportunities for achievement in school [6].

6. Multicultural education is a process of inculcating an attitude of mutual respect, sincerity, and tolerance for the diversity of ethnic, religious, and cultural diversity that exists in a pluralistic Indonesian society [7]. Through multicultural education, students who come from various ethnic/different backgrounds are guided to get to know each other about different religions, cultures, ways of life, customs, habits. More than that, students are taught to understand, acknowledge, and respect that each group has the right to express themselves in their own way. By teaching multicultural education, students are guided as early as possible to understand the meaning of Bhineka Tunggal Ika and implement it in everyday life [8].

7. In multicultural education, especially religious education, school should help pupils develop a respect for cultures other than their own. To accomplish this, we need to act before instruction begins to find out how our learners feel about other groups and cultures. This kind of diagnostic information provides insights regarding pupils' initial levels of sensitivity toward others. We can use this baseline information to prepare lesson to challenge stereotypes and extend pupils' appreciation of diversity. Pupils should be provided to work directly with members of different ethnic and racial groups. Direct contact with members of the other groups he makes young people to value new friends. These relationships help pupils to appreciate the ethnic and cultural groups to which their new friends belong. Pupils 
need to recognize the validity of different cultural perspectives. This goal seeks to expand pupils' conception of what it means to be humans. And so, religious education must also be able to help pupils develop pride in their cultural heritage.

\section{RELIGIOUS EDUCATION BASED ON THEOLOGY OF MUSLIM TEACHERS}

To be able to instill these multicultural values, Yogyakarta public elementary schools have shown a comprehensive awareness and understanding. The multicultural awareness of the religious teacher is rooted in the values of multiculturalism. Therefore, multiculturalism in Yogyakarta has significance in realizing peace because it requires that there is no domination of the majority culture. All of them grow together and have the same opportunity to achieve common prosperity. Each culture has the same opportunity to show its existence without discrimination [9]. Therefore, multiculturalism in Yogyakarta public elementary schools has empowered all potentials that exist in the community or students without distinguishing between religious and sociocultural backgrounds.

\section{A. Multicultural Understanding}

After studying religious life in several elementary schools, especially from the perspective of multicultural education, both related to conditions and the environment, curriculum, reference books, aspects of Islamic religious education teachers, it can be concluded that several public schools used as research areas have multicultural awareness and understanding. For example, there is a view that every individual is obliged to respect other individuals with different religions and traditions ${ }^{1}$. Likewise, based on interviews and observations at the Yogyakarta State Elementary School, in terms of thought and practice, Islamic religious education teachers have implemented Islamic religious learning in accordance with the basic framework of multicultural education. It is admitted that in certain areas, especially in the management of the environment and facilities, there are still a few things that are less than optimal, for example there are spaces that are less representative for learning other religions, besides Islam.

However, this condition is caused by the condition of the facilities that are still in the process of being perfected, not due to injustice and non-uniformity in student services ${ }^{2}$. The thoughts and practices of Islamic religious education teachers regarding multicultural education are appropriate. The attitude of students has also shown mutual respect and understanding, there are no limits in terms of association by each individual who has a different religion and tradition from others ${ }^{3}$. Admittedly, the people of Yogyakarta also have quite a variety of religious tendencies. As is the case in the Kotagede area, based on the results of research at public elementary schools there, the data shows that the thoughts

\footnotetext{
${ }^{1}$ This statement is based on the results of interviews with Islamic religious education teachers, books used as references, classroom situations, learning models and school conditions.

${ }^{2}$ Interview with the principal of Yogyakarta state elementary school, as the leader responsible for educational facilities.
}

and practices of Islamic religious education teachers regarding multicultural education are slightly different, especially those related to issues of theology or aqidah. The Islamic religious education teachers found in this school still show their priority to Islam, but Islam with a moderate orientation, not Islam which is interpreted and understood radically. However, what students do in their daily life, has reflected multicultural values. There are no certain limitations in the life of each student who has a different cultural background $^{4}$ [13]. The Islamic religious education teacher at the public school has shown and explained that there are other religions that are different besides the religion followed by the students.

There are adherents of other religions, apart from himself, who also embrace a certain religion. At the state elementary school, the students also vary in religion, the service of each student's spiritual activities is carried out well. There is no talk that certain religions are a minority among the followers of other religions which are more numerous. Every religious activity or any activity at school is usually done together, there is an assimilation to tolerate and help each other even between students of different religions ${ }^{5}$. Education services and enforcement of school regulations do not consider the social status of students. This public elementary school here has united students from various social statuses into one group and one class, so they can interact normally at school. Even so, the teacher does not mean to deny the difference. In the classroom and outside the classroom, the religion teacher still gave an understanding that in certain cases there were still differences among their friends. For example, some are rich, some are poor, some are beautiful and brave, some are mediocre, some are Muslim, some are Catholic Christians, Hindu Buddhists and so on. This understanding is not to create differences, an attitude of feeling superior to others, or an attitude of inferiority for those who are not perfect, but the goal is to instill an attitude of gratitude for whatever they have. Many of these issues were conveyed by teachers of Islamic religious education at the state elementary school, especially in Islamic subjects, especially those related to the discussion of Allah, the Creator and the One who governs everything in nature.

\section{B. Curriculum}

Basically, the Islamic religious learning curriculum in all Yogyakarta State Elementary Schools refers to the government curriculum. The subjects used as a source of competence refer to the provisions contained in the Law on the National Education System Number 20 of 2003, especially the provisions in Article 37. In addition to the subjects that are determined to form certain competencies, there is also a study load per week and per semester or per year. This learning load is then distributed to various subjects according to the expected competency demands. The Yogyakarta state elementary school curriculum uses an integrative thematic learning approach from grade I to grade VI. Integrative thematic learning is an approach that

\footnotetext{
${ }^{3}$ The results of observations in each school and interviews with several students.

${ }^{4}$ The results of observations at the Kotagede State Elementary School, one of the research locations in Yogyakarta.

${ }^{5}$ Interview with Mrs. Sri Lestari, Principal of the Demangan State Elementary School, one of the areas of this research was carried out.
} 
integrates various competencies from various subjects into various themes.

The integration is carried out through intra-disciplinary, multi-disciplinary, inter-disciplinary, and trans-disciplinary approaches. Intra-disciplinary integration is an effort to integrate attitudes, knowledge, and skills competencies into a unified whole in each subject. In addition, this integrative thematic is also enriched by the placement of Indonesian subjects as a driver for other subjects. Basic Competencies of local content relating to arts, culture, and skills as well as regional languages are integrated into the subjects of Cultural Arts and Crafts. Basic Competencies of local content relating to sports and regional games are integrated into Physical Education, Sports and Health subjects [10].

By referring to the concept proposed by Banks, the curriculum used in religious learning in Yogyakarta State Elementary already contains various approaches to integrating ethnicity and multicultural material into the curriculum. The first is called contribution. This approach is centered on studies of religious leaders, religious holidays and elements of different cultures, then the curriculum used is also additive. This can be seen in Islamic religious learning which has never changed the structure of the curriculum which contains content or material, concepts, themes in learning and the perspectives used. This approach is indeed greatly assisted by other means, such as relevant textbooks other than those prescribed by the government.

The second according to Banks, is transformation approach. This approach is completely different from the approach above because it includes fundamental changes that adapt to students' abilities, issues developed, and themes according to the cultural perspectives of different communities. In the context of learning Islamic religion in Yogyakarta State Elementary Schools, this approach has also been seen, although not optimally. Religious conflicts were also presented, but the issues raised did not cover a wider area, such as the history of conflicts, but only at the level of knowledge of elementary school students, for example someone who rarely gathers in society, lacks communication, shows off expensive and good clothes to each other ${ }^{6}$.

Besides these approaches, there is still a third approach called social action. According to Banks, this approach includes all elements of the transformation approach, but adds components that require students to make decisions an important social issue and take actions to help solve them, and this can reduce prejudice [11]. Students at Yogyakarta state elementary schools develop a caring attitude not to insult each other and are encouraged to help each other according to their respective abilities. Empathy and mutual help are not only instilled in the school environment. Sometimes there is time for students to be invited to social activities outside of school such as seeing a sick teacher or friend, or if there is a disaster among school members or other areas, students are invited to pray and make donations. This activity is never limited by religious factors and different traditions, and anyone who gets a student accident is always encouraged and invited to help ${ }^{7}$.

\footnotetext{
${ }^{6}$ Results of observations and interviews with Islamic religious education teachers at Yogyakarta state elementary schools.

7 The results of interviews with the Principals of the Demangan and Kotagede State Elementary Schools in the research area in Yogyakarta.
}

\section{ISLAMic RELIGIOUS EDUCATION TEACHER}

The role of teachers and schools in building a multicultural religious system for students at Yogyakarta State Elementary School can be concluded well. The role of Islamic religious education teachers here can be seen from their competence in learning and their ability to be democratic, both in words and in non-discriminatory attitudes. Then Islamic religious education teachers have a high concern for certain events that have to do with religion, not only to Muslim students but also to all students regardless of their religious and cultural background $^{8}$. Incidents and cases that harm humans are often presented at the beginning of the lesson, all of which aim to explain their concerns about these events.

Islamic religious education teachers also convey and explain that the essence of religious teachings is to create peace and prosperity for all mankind. Therefore, bombings to kill people, regardless of religion, military invasion, and all forms of violence are prohibited by Islam. Furthermore, the teacher has also been able to provide an understanding of the importance of dialogue and deliberation in solving various problems related to differences in religion. Of course, the delivery of religious material by Islamic religious education teachers at Yogyakarta State Elementary Schools has a distinctive style and method according to the cultural characteristics of students in each school. Apart from teachers, school institutions also play an important role in building a pluralist and tolerant educational environment.

The strategy adopted by the State Elementary School is, among others, building a sense of mutual understanding from an early age between students who have different beliefs. In several public elementary schools that became the research area, there were students who were Christian, also guided by Christian teachers. Likewise, the relationship between these different teachers seems to be harmonious, because that is a good example for elementary education students. In this case, the school has not yet played an active role in promoting interfaith dialogue with the guidance of the teachers in the school, due to the condition of the students who are still in the elementary level. Therefore, the doctrinal approach is still important, in addition to emphasizing the importance of respecting others. In each school, the pictures posted in the classrooms also show multicultural value. For example, there are pictures of religious facilities such as mosques, churches, and temples. There are also pictures of houses, clothes, dances, and customs of each community in Indonesia.

In the context of differences, an Islamic religious education teacher once said that there is 'Islam' and 'culture', both of which are two aspects that simultaneously enter into students. According to him, the way to be religious is to be cultured. If asked, which one entered the students first, religion or culture. According to him, this question is the same as answering where the chicken and the egg were created first. With this illustration, according to Rujito, that's how religious people are, nothing can be forced. All humans have received such a gift from God. In classroom learning, Islamic religious education teachers at Yogyakarta state elementary schools use teaching methods that can make students feel happy about

\footnotetext{
${ }^{8}$ The results of interviews with school principals and observations of the learning atmosphere in the classroom at Yogyakarta state elementary schools.
} 
learning Islam. The learning strategy used by the teacher has an important role in shaping the attitudes and behavior of students in a multicultural context. Without a good method, any good learning material will be difficult to understand well by students. As did an Islamic religious education teacher in one school, that at every lesson he always starts the lesson by telling stories first at the beginning of learning, for example telling stories about religious cases and peace ${ }^{9}$.

In general, teachers are able to make methods and learning media for Islamic religious education according to the needs and objective conditions of students in the basic education. In this context, Islamic religious education teachers design and use appropriate learning methods and media, so that they can motivate students to internalize and actualize the values of tolerance into concrete everyday life. Indeed, the process of inculcating values in Islamic religious education should not be fixed on one method alone but must be able to elaborate on various methods such as lectures, discussions, social actions, field trips or comparative studies.

\section{APPROACH IN ISLAMIC RELIGIOUS EDUCATION LEARNING}

The multicultural approach to Islamic religious education has been seen in public schools in the Yogyakarta city area, such as in the Demangan area and the Kotagede public elementary school. With a multicultural education approach, schools become an area to remove prejudice, and at the same time to train and build students' character so that they are able to be democratic, humanist and pluralist. There are two things that are done to construct multicultural education in schools, namely, first, conducting a dialogue by placing every civilization and culture on an equal footing. Second, develop tolerance to provide opportunities for students who have a distinctive culture to integrate with each other. Tolerance here is not only at the conceptual level, but also at the operational technique.

As mentioned earlier, the approaches that can be used in the learning process in multicultural classrooms are a single group approach and a multiple perspective approach [12]. Multicultural education in several elementary schools generally uses a single group study approach. Although it was not prepared from the start, it is understandable that what the teachers were doing there was able to assist students in studying the views of certain groups in more detail. To support this, this institution prepares various data on the history of community groups, their customs, clothes, pictures of houses, types of food, religious beliefs, and other traditions. This approach is centered on the issues that are full of the values of the group being studied.

Meanwhile, the Multiple Perspectives Approach is an approach that focuses on a single issue that is discussed from the perspectives of different groups. In general, teachers have various perspectives in their learning. In this view, Bennett and Spalding suggest that learning uses a dual perspective approach, arguing that this approach appears to be more

\footnotetext{
9 The results of the interview with the teacher of Islamic religious education, Mr. Rujito.

${ }^{10}$ Search results of reading books for PPKN subjects (Pancasila and citizenship education) which are used as references in Yogyakarta state schools.
}

effective. This dual perspective approach helps students to realize that common events are often interpreted differently by others, whose interpretation is often based on the values of the group they belong to. Solutions that are considered good by one group (because the solution is in accordance with their values), are often not considered good by other groups because they do not match the values they follow. The advantage of this dual perspective approach lies in the students' critical thinking process on the topic being discussed so as to encourage them to eliminate bad prejudices. Interaction with different group views allows students to empathize [13].

Learning materials and learning activities that are rich with nuances of affection have proven to be able to develop a flexible perspective on living together in different cultures. Students who have great empathy allow him to respect different points of view. Of course, it will be able to reduce prejudice against other groups. Reading a lot of regional culture books that contain the views and traditions of the Indonesian people, for example, is actually able to reduce stereotypes about other people's cultures [14]. The dual perspective approach contains two goals, namely increasing empathy and reducing prejudice. Empathy for different cultures is a prerequisite for reducing prejudice ${ }^{10}$. The aesthetic approach basically teaches students to be able to be polite and courteous, peaceful, friendly, and love beauty. In the learning process, almost all Islamic religious material is explained not only doctrinally and suppresses the existence of truth authorities, but also by appreciating all the symptoms that occur in society by seeing it as part of the dynamics of life that has artistic and aesthetic value. Rujito, an Islamic religion teacher, said that Islam should be taught through a cultural approach, not intimidating and oppressing students ${ }^{11}$.

Multicultural Islamic theology, as a teacher's perspective, is seen in classroom learning. Islamic religious education teachers have used effective teaching methods, by increasing students' learning opportunities and considering the varied cultural backgrounds of students. Islamic religious education teachers have become role models for displaying behaviors and attitudes that reflect multicultural principles. As the implementer of the curriculum, a teacher is required to present Islamic teachings that are peaceful and spacious. The doctrines of Islamic teachings are presented with materials that are inclusive and respect differences, without having to reduce the beliefs of the teachings they adhere to. Teachers have been able to give a clear message that Islam is a religion that gives mercy to the universe. Thus, it is appropriate that when students study Islamic education, their behavior should reflect grace for all nature by respecting diversity and respecting differences.

The choice of teacher strategy in developing learning seems to have been able to help the realization of multicultural-based Islamic religious education. In the teaching-learning process through a multicultural approach, the use of cooperative learning strategies has been used. Here, students can learn while playing with their friends from

\footnotetext{
${ }^{11}$ Interview with Mr. Rujito, one of the teachers of Islamic religious education
} 
different religions. This strategy is proven to be able to increase the level of student participation in making recommendations for peaceful diversity values and building a paradigm of unity in diversity. In cooperative learning there are several aspects that become a reference for multiculturalbased religious learning, in this aspect, students are required to have the skills to develop life skills in respecting diversity, tolerance for differences, accommodating, open and honest in interacting with friends (others) of different ethnicity, religion, ethnicity and culture.

\section{Content of Multicultural Islamic EducAtion}

In order to build a variety of religions in Yogyakarta public elementary schools, there are several Islamic religious education materials that have been developed using a multicultural approach.

\section{A. Qur'an}

In Qur'an teaching materials, religious teachers prepare verses about faith, but also by adding verses or teachings that contain the importance of maintaining relationships with other people. The verses of the Qur'an that are taught, for example, are related to the recognition of the Qur'an for the existence of plurality and competing in goodness as in surat al-Baqarah verse 148; verses relating to the recognition of peaceful coexistence in inter-religious relations as in surat alMumtahanah verses 8-9; and verses related to justice and equality as in surat an-Nisa 'verse 135 .

In several basic education institutions, Islamic religious learning has used the 2013 curriculum published by the government, and the discussion is thematic. There are four kinds of competencies developed. The four core competencies are related to religious attitudes, social attitudes, knowledge, and application of knowledge. The four competencies become the reference of basic competencies and must be developed in every learning event in an integrative way. Competencies related to religious and social attitudes are developed indirectly (indirect teaching), namely when students learn about knowledge and apply knowledge. Verses such as in surat al-Baqarah verse 148 which relate to the acknowledgment of the Qur'an for the existence of plurality and competing in goodness have been conveyed; Likewise the material related to the recognition of peaceful co-existence in inter-religious relations in surat alMumtahanah verses 8-9; verses related to justice and equality in an-Nisa 'verse 135, have been textually listed, especially in the modules and textbooks used [15].

\section{B. Faith/Theology Material}

Not all theological materials, especially the pillars of faith, are described in this study. The material that is more relevant in the context of multiculturalism here is related to faith in books and apostles, for example. Belief in Allah's books is the third pillar of faith. The Book of Allah is the revelation of Allah which was revealed to the messengers who received it and the revelation has been written and recorded. There is also God's revelation that was received to the apostles and not recorded, namely what is called Suhuf. Among the messengers who received the temperature were Prophet Ibrahim and Prophet Musa. Muslims are obliged to believe and firmly believe that all the books that Allah has revealed to His Messengers must be true. This is based on the word of Allah in the surat an-Nisa 'verse 136: "O you who believe, keep believing in Allah and His messenger and in the book that Allah sent down to His messenger and the books that were revealed earlier." The books referred to in the verse above contain regulations, provisions, commands, and prohibitions that are used as guidelines for mankind in carrying out life in order to achieve happiness in life in this world and the hereafter.

The books of God were revealed at different times, but they contain the same basic teachings, namely the teachings of monotheism or the teachings of the oneness of God. The difference is only in terms of the shari'a or local laws that are adapted to the times and conditions of the people at that time. There are 4 books of Allah that we must believe in, namely: the Torah, the Bible, the Zabur and the Qur'an. Likewise, each of the Apostles who received the books of Allah. In several statements, religious teachers said that the Prophet Moses received the Torah in Hebrew as a way of life for the Children of Israel. The word of God in the Qur'an surat al-Maidah verse 44 states: "Indeed We have sent down the Torah in it (there is) guidance and light (which illuminates)".

According to some Muslims, currently the original Torah which contains the creed and the laws of the Shari'ah is no longer found. What is found among the Jews today is not the Torah that is in accordance with the original, because they have made changes to its contents (teachings). The present Torah is more accurately said to be written or rewritten by the Jews at a different time and time. This statement is based on the word of Allah in surat an-Nisa verse 46, "That is, the Jews they change the words from their places..." However, this view is not entirely accepted by Muslims, especially those with moderate and liberal views. This group does not only look at the aspect of the teachings of revelation from the textual, but also on the aspect of its substance and context. The book of Zabur was revealed by Allah to the prophet David in Qibti language and was intended for the Children of Israel. Prophet David was only ordered by Allah to follow the Shari'ah of Prophet Moses. The main teachings of the Zabur book contain remembrance, advice and wisdom, and worship songs, this book does not contain shari'ah. The word of God in surat al-Isra 'verse 55 states "And we gave the Zabur to David." Furthermore, Allah revealed a book to Prophet Moses in Syriac language and destined for the Children of Israel, namely the Bible. The original Bible contains true and real information, namely God's commands so that humans unite Him and not associate Him with anything. The Bible also explains that at the end of time the last prophet will be born. In surat al-Maidah verse 46 it is stated: "And We have given him (Isa) the Gospel, while in it (there is) guidance and light (which illuminates)."

The last book revealed by Allah is the Qur'an. This book was revealed to the Prophet Muhammad as the last prophet. The Qur'an is the word of Allah revealed to the Prophet Muhammad through the intermediary of the angel Gabriel in Arabic and is intended for all mankind in the world. The Qur'an is also the greatest miracle of the Prophet Muhammad. The Qur'an is a miracle because it can weaken the Quraish disbelievers who like to make poetry. The poems made by the Quraish disbelievers at that time were not able to compete 
with the beauty of the verses of the Qur'an. The Qur'an is a complement to the previous books so it can be concluded that the contents of the Qur'an do not conflict with the previous books. On the other hand, the contents of the previous books are contained in the Qur'an.

As a guide for human life that has been perfected, the contents of the Qur'an are very complete covering all aspects of life. The contents of the Qur'an include: 1) Faith/ monotheism, which contains about God, the Angels, the Book of Allah, the Prophets and Apostles, the Day of Judgment and the provisions of Allah. 2) Worship, namely humans were created nothing but to worship God. The procedures for this worship have also been regulated in the Qur'an. For example, prayer, zakat, fasting and hajj. Even the procedure for purification is regulated in the Qur'an. 3) Science, namely in the Qur'an contains a lot of knowledge that supports current technological advances. It also includes the health sciences, astronomy, agriculture and so on. 4) Law, namely in human life given various rules such as the law of marriage, buying and selling, stealing, adultery and many more. 5) History, namely that in the Qur'an many stories of previous humans are told, both those who behaved well and bad. Likewise in the form of stories about the Prophets, pious people and people who disobey Allah have been contained in the Qur'an which can be taken as an example in life. 6) News, which is a description of the life that will be experienced by humans in the hereafter, where people who believe will go to heaven and those who disobey Allah will be put into hell. All of these fields are the inspiration for Islamic religious education materials in basic education in public elementary schools. Based on these data, there is no information and some core teaching materials that tend to conflict and hatred. Issues of differences that lead to hatred are not addressed in classroom learning.

\section{Islamic Jurisprudence}

Islamic religious education materials related to fikih or Islamic jurisprudence are only at the basic level discussion. That is, the material presented has only revolved around the issue of purification, prayer, fasting. Of course, there is no material related to the study of Islamic law in the field of politics (government) in detail, for example. From political Islamic jurisprudence, only issues of nationality that have been exemplified at the time of the Prophet, the Companions, or the caliphs after him have been presented, no more than that. At the time of the Prophet, for example, how did Prophet Muhammad manage and lead the multi-ethnic, multi-cultural, and multi-religious Medina community. The situation of the people of Medina at that time was not much different from the people of Indonesia, who were also multi-ethnic, multicultural, and multi-religious. This is the illustration that was delivered by the teacher in class. In Islamic jurisprudence, the multicultural aspect is seen when the teacher conveys that there are differences in the implementation of prayers, especially at dawn prayers, namely that some read the qunut (prayer text in the morning prayer) and some do not.

\section{Morals}

The moral material delivered at public elementary schools focuses their studies on good and bad behavior towards Allah, Prophets, fellow human beings, oneself, and the environment. In the context of nationality, this is indeed important to teach.
Because, the survival of a nation depends on morals, if a nation underestimates morality, the nation is extinct. Religious education with a multicultural nuance can be effective, because from the beginning the Islamic religion teachers in this public school have conveyed the problem. In addition to always developing varied teaching methods, not monotonous, Islamic religious teachers have also provided examples related to morals. In learning at school, it was conveyed that the Qur'an had talked about the destruction of the people of prophet Lut, due to the collapse of moral foundations.

There is also a discussion about being kind in the learning materials. This is relevant to multicultural education, because one of the causes of disharmony in relations between individuals or between groups of people in a multicultural country is the existence of an attitude of bad prejudice between them. Prejudice usually tends to generalize in viewing and judging another person or group regardless of the fact that each individual has a different character. In a multicultural society, prejudice can easily grow, this situation usually causes discrimination and conflict between individuals or groups with one another. In this material about being kind, the explanation is not so specific about the theme of multiculturalism. But the illustrations delivered by the teacher already contain these values. In moral learning, material related to discrimination as despicable morals is also delivered in class. The essence of discrimination is the unfair treatment directed at certain groups of people.

This material is delivered simultaneously when the teacher teaches material about God's justice. This theme covers and covers multicultural issues, the explanation is not limited to making a definition of what is meant by fair, but also accompanied by a very in-depth explanation, as well as real examples in the community and students themselves. Regarding the moral material, the reference book also found a story about the Prophet Muhammad who allowed a Jew of a different religion to come and live in his house without expelling him. The Prophet did not forbid it or by saying: "You Jews are not allowed to live in my house", not so the character of the Prophet Muhammad. The Jew lived with the Prophet Muhammad and slept there, ate a plate with the Prophet, brought the Prophet drinking water, as if he had become part of the Prophet Muhammad's own family. A Jew, as a friend of the Prophet, was never forced to convert to Islam, one time he was sick and the Prophet visited him, and the Prophet did not say: fortunately, the Jew is sick, so he no longer lives in my house.

The Prophet was not like that, instead he said: "Where is the Jew who lives in my house, why did he go, what was my fault that he left me. After the Prophet arrived at the house of the Jew, it turned out that he was close to death. Then the Prophet said: "O young man, will you say "La ilaaha illallah Muhammad Rasulullah?" (There is no god but Allah, Muhammad is the messenger of Allah), the young man hesitated to say it, then he turned to his father who was also a Jew, then his father said: "That's right, follow Aba Al Qasim and follow his words. that." Then the young man did it, and soon died. Suddenly the expression of the Prophet's face changed with joy and joy because he saw the Jew who lived in his house died in a state of Islam, so the beauty of religious harmony. 


\section{E. History of Islam}

Materials that are based on historical facts and realities can be exemplified in the social interaction practices applied by the Prophet Muhammad when building the people of Medina. From the historical aspect, the Medina development process carried out by the Prophet Muhammad contained facts about the recognition and appreciation of the values of pluralism and tolerance. The understanding of pluralism and tolerance that is properly instilled in students is not based on the curriculum and syllabus but is only based on an understanding of the nature and character of the Prophet Muhammad. In this context, in schools, for example, students are gradually trained to eliminate primordial barriers by presenting religious learning based on plurality and togetherness.

To get this result, the learning method developed is no longer indoctrination but a dialogical atmosphere. Students are shown the fact of plurality as well as explore the value of humanity. School activities and learning models are always conditioned based on togetherness and cooperation. In other words, the Islamic religious education curriculum found in Yogyakarta public elementary schools has been initiated with an inclusivism frame. The books that are used as references for discussing the history of Islamic culture are books that contain friendly relations between you Muslims and nonMuslims. In Medina, for example, besides the Muslim Arabs, there are also groups of Jews and Arabs who still adhere to the religion of their ancestors. At the end of the discussion of Islamic history, students are also taught how to spread Islam by the prophet, namely without coercion and violence, wise ways (wisdom), and with good teaching. Islamic teachings about equal rights and the rejection of the caste system and discrimination, it is easy to attract students' sympathy in the context of understanding them to respect other people of different religions and traditions.

\section{COnClusion}

The concept of multicultural Islamic religious education at State Elementary Schools in the city of Yogyakarta implies maintaining and prioritizing Islam as the norm, but it does not deny that there are differences in other beliefs that must be maintained. Islam as a religion embraced by Islamic religious teachers does not necessarily make them invite students to take a confrontational attitude from students of different religions or traditions. Islamic religious learning in public elementary schools in the city of Yogyakarta applies multicultural models or approaches. In learning, for example, there are no negative attitudes or suggestions to other people of different religions or traditions, on the contrary, that religious learning emphasizes how important it is to respect and protect every human being. Regarding the reference book used, there are indeed some unbalanced explanations. In terms of discussing theology, for example, the portion of material for certain prophets and scriptures can be more than others. There are two possibilities why this happens in the writing of textbooks, The first is that it is intentionally done by the authors (contributors), because it is in accordance with the author's ideology. The second possibility is that the authors may not have sufficient references to explain it in the textbooks they write. But the teacher was already careful about this situation.

\section{REFERENCES}

[1] J. J. Fox, "Opening to The Future: Multicultural Education in An Islamic Contextle," presented at the Internasional Seminar on Multicultural Education, Cross Cultural Understanding For Democracy and Justice, Yogyakarta, 2005.

[2] T. V. Savage and D. G. Amstrong, Effective Teaching in Elemntary Social Studies, New Jersey: Prentice Hall, Inc, 1996.

[3] J. Levy, "Multicultural Education and Democracy in the United State," presented at the International Seminar on Multicultural Education, Cross Cultural Understanding For Democracy and Justice," Yogyakarta, 2005.

[4] S. Nieto, "Multicultural Education and School Reform in Language, Cultural and Teaching," Mahwah NJ: Lawrence Erlbaum, 2002.

[5] J. Banks, "Multicultural Education: Characteristics and Goals," in Multicultural Education: Issues and perspectives, New York: John Wiley\&Son, 2003.

[6] Arthur K. Ellis, Teaching and Learning Elementary Social Studies, London: Allyn and Bacon, 1998;

[7] M. Asy'arie, "Pendidikan Multikultural dan Konflik Bangsa," Harian Kompas, Jakarta, 2004.

[8] M. Buchori, "Pendidikan Multikultural," 2007. http//www.paramadina.wordpress. com.

[9] C. Mahfud, "Pendidikan Multikultural," Yogyakarta: Pustaka Pelajar, 2006.

[10] The Curriculum of the Ministry of Education and Culture, Basic Competencies of Elementary Schools/Madrasah Ibtidaiyah, 2013".

[11] James Banks, Multicultural Education: Historical Development, Dimension, and Practice, USA: Review of Research in Education, 1993.

[12] Munawwir Hadiwijaya and Adi, “The Implementation of Multicultural Based Learning in Reducing Intolerance Attitudes among Students", Journal of English Teaching, Literature, and Applied Linguistics, vol. 2, No. 2; August 2018.

[13] E. Bennett and C. Spalding, "Teaching the Social Studies: Multiple Approaches for Multiple Perspectives," Theory and Reseach in Social Education 20(3): 263-292, 1992.

[14] A. Rusli, Tematik Atlas Provinsi Sumatera Selatan, Jakarta: PT Karya Pembina Sanjaya, 2007.

[15] A. Hasyim, PAI/SD MI, Islamic Religious Education, Ministry of Education, Jakarta2014.

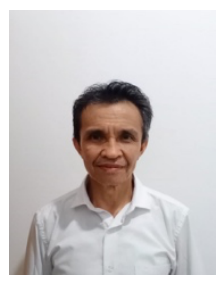

S. Sirait was born in Asahan in 1959, a region of North Sumatera with the capital city of Medan, Indonesia. In 2006, he obtained a doctorate in Islamic Studies from the State Islamic University of Sunan Kalijaga, Yogyakarta. His published articles include Religious Attitudes of Theological Traditionalist in the Modern Muslim Community: Study on Tahlilan in Kotagede; Moderate Muslim: Mapping the Ideology of Mass Islamic Organizations in Indonesia; Dialectic Of Theology And Mysticism In Islam: A Study Of Ibn Taymiyya. Until now, he is working as a professor of Islamic theology at the Faculty of Education and Teacher Training at Sunan Kalijaga State Islamic University, Yogyakarta. Sangkot Sirait, Prof. Dr. MA is also active in educational trainings, especially the training of professional teachers of Islamic education. 